Canadian University Music Review

Revue de musique des universités canadiennes

\title{
Dietrich Bartel. Musica Poetica: Musical-Rhetorical Figures in the German Baroque. Lincoln and London: University of Nebraska Press, 1997. xv, 471 pp. ISBN 0-8032-1276-3 (hardcover)
}

\section{Lisa Szeker-Madden}

Volume 19, numéro 1, 1998

URI : https://id.erudit.org/iderudit/1014611ar

DOI : https://doi.org/10.7202/1014611ar

Aller au sommaire du numéro

Éditeur(s)

Canadian University Music Society / Société de musique des universités canadiennes

ISSN

0710-0353 (imprimé)

2291-2436 (numérique)

Découvrir la revue

Citer ce compte rendu

Szeker-Madden, L. (1998). Compte rendu de [Dietrich Bartel. Musica Poetica: Musical-Rhetorical Figures in the German Baroque. Lincoln and London: University of Nebraska Press, 1997. xv, 471 pp. ISBN 0-8032-1276-3 (hardcover)]. Canadian University Music Review / Revue de musique des universités canadiennes, 19(1), 94-96. https://doi.org/10.7202/1014611ar

All Rights Reserved (C Canadian University Music Society / Société de musique des universités canadiennes, 1998
Ce document est protégé par la loi sur le droit d'auteur. L'utilisation des services d'Érudit (y compris la reproduction) est assujettie à sa politique d'utilisation que vous pouvez consulter en ligne.

https://apropos.erudit.org/fr/usagers/politique-dutilisation/ 
these same churches are in the grip of demographic and cultural changes that few 1920s-era pioneers could have imagined. Dwindling membership and finances, radical revisions of liturgical ideals, and a desire on the part of some to bring church music more closely into accord with the popular music of the day have "produce[d] a generation of worshippers unfamiliar with the organ, its musical heritage, and its literature" (p. 213). To these factors we must add the ready availability of comparatively inexpensive electronic substitutes, which have developed to a point at which many (if not most) untrained listeners have difficulty distinguishing their sound from that of a pipe organ. This, Hartman concedes, "further diminishes the probability of even a small number of pipe organ installations in future years" (p. 211).

To argue, therefore, that "[i]nterest in the organ music [sic] is still relatively strong ... [t] $]$ here is no reason to suppose that this trend will be reversed in the coming years" (p. 215) is perhaps to indulge in a species of wishful thinking. A more dispassionate evaluation of the organ's prospects, however, whether in Manitoba or in Canada as a whole, suggests an increasing marginalization of the instrument as mainline churches change almost beyond recognition. The organ's future, despite Hartman's optimism, is very uncertain. One feels almost churlish suggesting it-given the quality of this book-but his history of the Manitoba organ might turn out to be more complete than he would wish.

Those at the University of Manitoba Press responsible for the production of this volume are to be commended. The book is well-designed, illustrations are appropriate and clearly reproduced, and the typography is clean and readable. Few misprints have escaped the proofreader's eye, and those that remain are for the most part minor (e.g., in the St. Boniface Cathedral specification on p. 257 , the Pédale Quinte $22 / 3$ should be Quinte $102 / 3$ ). James Hartman and his publishers have provided a balanced, thorough, and needed account of organs and organists in Manitoba; one hopes that their counterparts elsewhere in the country follow suit.

Thomas Chase

Dietrich Bartel. Musica Poetica: Musical-Rhetorical Figures in the German Baroque. Lincoln and London: University of Nebraska Press, 1997. xv, 471 pp. ISBN 0-8032-1276-3 (hardcover).

When scholarship in the field of English literature began to take an interest in historically informed methodologies, Lee A. Sonnino published A Handbook to Sixteenth-Century Rhetoric. ${ }^{1}$ With its alphabetical compilation of textualrhetorical figures as defined in various primary sources, coupled with its appendices that aid in the finding of particular figures, this work has since become a standard resource tool. A similar undertaking by Dietrich Bartel in the field of musical rhetoric resulted in his Handbuch der musikalischen Figurenlehre (Laaber: Laaber Verlag, 1985), a work which has also become a

1 Lee A. Sonnino, A Handbook to Sixteenth Century Rhetoric (London: Routledge and Kegan Paul, 1968). 
standard source. Bartel's latest effort presents a revised, expanded and translated version of his earlier work.

Bartel divides the book into three major parts. The first part, "Introduction to the Concepts," presents new material that is not present in his original Handbuch. Four chapters make up the material of this first part. The opening chapter, "Luther on Music: A Theological Basis for German Baroque Music," provides a summary of Luther's writings on music. In short, Luther views music as "a divine gift to humanity" (p. 3), the most important element of the quadrivium (p. 4), and fundamental in the education of children (p. 7). The second chapter, "Toward Musica Poetica: The Emergence of German Baroque Music" describes the shift in pedagogical emphasis from music as linked to speculative mathematics to a musica poetica that embraces the concepts of rhetoric and oratory. In addition, Bartel demonstrates the progression of musical rhetorical emphasis from elaboration of the text to a more general expression of the affections. Citing Johann Mattheson, Johann Adolph Scheibe, and Johann Nikolaus Forkel, Bartel contends that, as a result of this shift, musica poetica became relevant to both vocal and instrumental compositions by the beginning of the eighteenth century (p. 24). In the next chapter, "The Concept of the Affections in German Baroque Music," Bartel discusses the relationship between the affections and such compositional parameters as key, mode, rhythm, and text. Here, Bartel acknowledges that composers relied more on rhetoric than on "the frequently contradictory concepts of mode or key characteristics" (p. 46). The final chapter of the first part, "Principles of Rhetoric in German Baroque Music," describes the dissemination of rhetoric as a part of the Lateinschule curriculum. It also links musical rhetorical concepts with their counterparts in literary rhetoric.

The remaining parts of the book, "Treatises and Sources" and "Definitions and Translations of the Musical-Rhetorical Figures," are largely taken from his earlier work. "Treatises and Sources" outlines the musical rhetorical sources in more detail. Bartel opens each discussion with a brief biography of the author, followed by a summary of the pertinent material of each treatise. Bartel's useful comparison and contrast of the sources in chronological context confirms the development of musica poetica from its textual and theological orientation during the Renaissance to its affective orientation during the Baroque period.

It is in the third part of the book that its true value emerges. In this, the largest part of the work, Bartel presents the musical rhetorical figures in alphabetical order. He begins each definition with his own summarized interpretation. This is followed by a presentation of the definitions as they exist in their original sources coupled with their page number references, musical examples where extant, and Bartel's translations. Several useful appendices are provided in order to aid the analyst in finding the appropriate figures of a work. Assume, for instance, that one requires the musical-rhetorical term for a device where repetitions of a melodic motif rise by step. A search through "Appendix 2: Summary of the Figures by Category" leads the analyst to "Part A: Figures of 
Melodic Repetition," and specifically to the figure auxesis, incrementum. Armed with the correct terminology, the analyst can then easily locate Bartel's discussion of the figure (pp. 209-10), followed by his chronological presentation of its various definitions (pp. 210-12). Other appendices include: summary of figure definitions (in alphabetical order), list of figures by author, and summary of figures by author. The number and variety of appendices combine to present a comprehensive consideration of each figure in its historical context.

It is unfortunate to note, however, that some of Bartel's work, particularly in the first part of the book, is problematic and contradictory. For example, in chapter 3, Bartel agrees with George Buelow that a comprehensive and consistent Doctrine of the Affections did not exist during the Baroque period (p. 30). At the same time, however, Bartel states that the Baroque composer

had a concrete and well-defined understanding of the affections. The desired affection could be presented and aroused through the appropriate mode or key, time signature and tempo, figure and cadence ... (p. 33)

Yet, a few pages later, he again argues against a doctrine of the affections (p. 39). The confusion here arises from the fact that while Baroque composers and theorists agreed that music had the power to move the affections of the auditors, they disagreed as to how this could be accomplished. Indeed, it is this fundamental lack of consensus among the sources that undermines a Doctrine of the Affections more than Bartel's contention that "musical devices and idioms which might arouse a certain passion in one listener may not succeed to the same degree in another listener" (p. 39).

Besides contradictions, the first part has organizational problems. For instance, Bartel includes similar discussions of the "affective words" in both chapters 2 and 3. Along the same lines, Bartel presents complex rhetorical terminology as early as p. 23 of the book that he does not define until p. 66 . Also problematic is Bartel's use of certain terms interchangeably without commenting on their distinctions, as, for instance cantor (Latin) vs. Kantor (German) (pp. 11-12) and affection vs. passion (pp. 53, 72). Even more perplexing is the fact that Bartel undermines his remarkable and often provocative conclusions by not providing the appropriate documentation. Such is the case regarding his discussions of the cantor's duties (p. 12), the curriculum of the Lateinschule (pp. 65-66), and his conclusion that students did in fact learn the principles of musical rhetoric (p. 74).

None of these criticisms, however, should take anything away from Bartel's monumental effort, nor the value of his work in the field of musical-rhetorical scholarship. I am certain that the significance of this work will reverberate for years to come. 